\title{
Sports Medicine Imaging
}

Editors

NICHOLAS C. NACEY

JENNIFER L. PIERCE

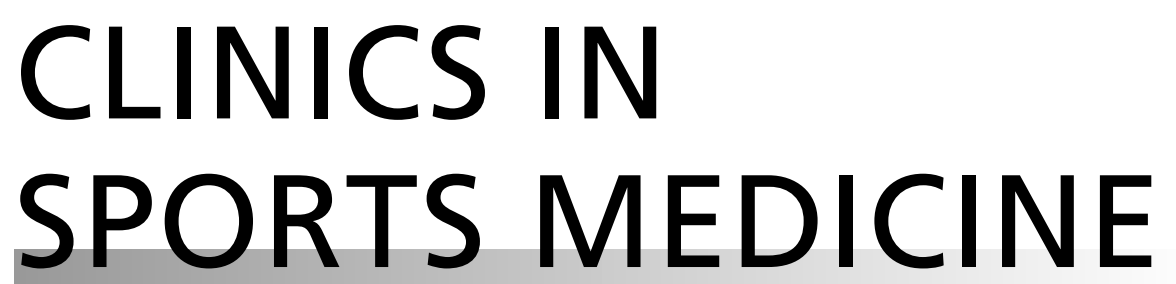

www.sportsmed.theclinics.com

Consulting Editor

MARK D. MILLER

October 2021 • Volume $40 \bullet$ Number 4 